\title{
GAMBARAN ANEMIA PADA PENDERITA PENYAKIT GINJAL KRONIK DI BLU. RSUP. PROF. DR. R. D. KANDOU
}

\author{
${ }^{1}$ Dwifrista Vani Pali \\ ${ }^{2}$ Emma Sy. Moeis \\ ${ }^{3}$ Linda W. A. Rotty \\ Bagian Ilmu Penyakit Dalam Fakultas Kedokteran Universitas Sam Ratulangi \\ Email :dwifristavpali09237@yahoo.com
}

\begin{abstract}
Anemia is the most common complication in patient with Chronic Kidney Disease (CKD). Anemia itself coud be a risk predictor to cardiovascular event and prognosis to kidney disease itself. The goal is to know the profile of anemia on CKD patient at Prof. Dr. R. D. Kandou Hospital Manado. The methods in this research is the observasional study with cross sectional device in CKD patient $\mathrm{s}$ tage 3, 4, and 5 at at Prof. Dr. R. D. Kandou Hospital Manado.

The results are from 25 total patient who included in research criterion there $15(60 \%)$ man and $10(40 \%)$ woman, age distribution basic on CKD stages, Group of age 30-40 have 1(4\%) in stage 4, $2(8 \%)$ in stage 5, group 36-40 in stage 3 theres $2(8 \%)$, in stage $42(8 \%)$. Group $41-455(20 \%)$ in stage 4 and $3(12 \%)$ in stage 5. Group 46-50 $3(12 \%)$ in stage 3, 2(8\%) in stage 4 and 5(20\%) in stage 5. Anemia distribution basic on CKD stages, normal iron deficiency there's 4 people in stage 3.4 people in stage 6 , and 4 people stage 5 . Iron deficiency fungtional 1 person in stage 3, 4 people in stage 4 and 4 people in stage 5. Iron deficiency absolute there's 2 people in stage 5.

The Conclusions in this research is the most status of anemia in this research is normal iron deficiency are 14 people
\end{abstract}

Key Words : Anemia, CKD, Transferrin Saturation, Ferittin Serum

\begin{abstract}
Abstrak : Latar Belakang dari penelitian ini yaitu anemia merupakan komplikasi yang sering terjadi pada penyakit ginjal kronik (PGK). Anemia sendiri juga dapat menjadi prediktor resiko terjadinya kejadian kardiovaskular dan prognosis dari penyakit ginjal sendiri. Tujuan dari penelitian ini adalah untuk mengetahui gambaran anemia pada penderita PGK di poliklinik ginjal - hipertensi bagian ilmu penyakit dalam BLU.RSU. Prof.dr R.D Kandou Manado. Metodologi Penelitian ini bersifat observasional dengan rancangan potong lintang pada pasien (PGK) stadium 3, 4, dan 5 di poliklinik ginjal - hipertensi bagian ilmu penyakit dalam BLU.RSU. Prof.dr R.D Kandou Manado selama kurun waktu 2 bulan (November-Desember 2012) .Hasil dari peneltian ini adalah dari 25 pasien yang memenuhi kriteria inklusi terdapat $15(60 \%)$ pasien laki-laki dan $10(40 \%)$ perempuan, distribusi umur berdasarkan derajat PGK kategori umur 30-40 tahun terdapat 1 (4\%) orang pada stadium 4, 2(8\%) pada stadium 5. Kategori 36-40 terdapat 2(8\%) orang pada stadium 3, 2 (8\%) pada stadium 4. Kategori umur 41-45, 5(20\%) orang pada stadium 4 dan 3(12\%) orang pada stadium 5. Kategori 46-50 terdapat 3(12\%) orang pada stadium 3, 2(8\%) pada stadium 4 dan 5(20\%) pada stadium 5. Distribusi anemia berdasarkan derajat PGK, anemia defisiensi besi cukup terdapat 4 orang pada stadium 3,4 orang stadium 6, 4 orang stadium 5. Anemia defisiensi besi fungsional stadium 3, 1 orang. Stadium 4, 4orang. Stadium 5, 4 orang. Anemia defisiensi besi absolut terdapat 2 orang stadium 5. Kesimpulan dari penelitian ini adalah kasus terbanyak yaitu anemia defisiensi besi cukup yaitu 14 orang.

Kata Kunci : Anemia, PGK, Saturasi Transferin, Serum Feritin
\end{abstract}

\section{PENDAHULUAN}

Definisi penyakit ginjal kronik (PGK) berdasarkan National Kidney Foundation (NKF) Kidney Disease Outcome Quality Initiative (KDOQI) Guidelines update tahun 2002 adalah kerusakan ginjal $>3$ bulan, berupa kelainan struktural ginjal, dapat atau tanpa disertai penurunan Laju Filtrasi Glomerulus (LFG) yang ditandai dengan kelainan patologi dan adanya pertanda kerusakan ginjal, dapat berupa kelainan laboratorium darah atau urine atau kelainan radiologi. $\mathrm{LFG}<60 \mathrm{~mL} / \mathrm{menit} / 1,73 \mathrm{~m}^{2}$ selama $>3$ bulan, dapat disertai atau tanpa disertai kerusakan ginjal. ${ }^{1}$ 
Penyakit ginjal kronik merupakan masalah kesehatan masyarakat di seluruh dunia, insiden dan prevalensi penyakit ginjal meningkat di Amerika Serikat, dari 340.000 orang pada tahun 1999 menjadi 651.000 orang pada tahun 2010. Pada penelitannya, Bliwise $\mathrm{dkk}^{2}$ menyatakan bahwa di Amerika Serikat tiap tahunnya lebih dari 300.000 pasien menerima terapi hemodialisis dengan tingat kematian tiap tahunnya sekitar $20 \%$.

Berdasarkan data di beberapa pusat nefrologi di Indonesia, diperkirakan insiden PGK berkisar 100-150/juta penduduk dan prevalensinya 200-250/juta penduduk pada tahun 2005 . $^{3}$ Anemia merupakan komplikasi PGK yang sering terjadi, bahkan dapat terjadi lebih awal dibandingkan komplikasi PGK lainnya dan pada hampir semua pasien PGK. Anemia sendiri juga dapat meningkatkan risiko morbiditas dan mortalitas secara bermakna dari PGK. Adanya anemia pada pasien dengan PGK dapat dipakai sebagai prediktor risiko terjadinya kejadian kardiovaskular dan prognosis dari penyakit ginjal sendiri. Menurut data dari The Third National Health and Examination Survey (NHANES III), yang dikutip oleh penelitian Ayu Nyoman $\mathrm{dkk}^{4}$ kejadian anemia yang ditandai dengan kadar hemoglobin $<11 \mathrm{~g} / \mathrm{dl}$ sebesar 80.000 orang. Pada pasien pradialisis dengan LFG kurang dari 60ml/mnt/1,73 (PGK stadium 3-5), kejadian anemia dengan kadar hemoglobin kurang atau sama dengan $12 \mathrm{~g} / \mathrm{dl}$ adalah sebesar 50\%. Anemia pada PGK ditandai dengan morfologi normokrom normokromik normositer, setelah disingkirkan kemungkinan anemia karena sebab lain seperti anemia karena hemodialisis, kekurangan zat besi, asam folat atau B12 dan keganasan, baik keganasan hematologi maupun bukan hematologi.

Berdasarkan uraian diatas peneliti ingin untuk mengetahui gambaran anemia pada penderita PGK di di BLU.RSU. Prof.dr R.D Kandou

\section{METODE PENELITIAN}

Desain Penelitian ini bersifat observasional dengan rancangan potong lintang.

Penelitian ini dilakukan di poliklinik ginjal - hipertensi bagian penyakit dalam BLU.RSUP. Prof.dr R.D Kandou. Penelitian dilakukan dalam jangka waktu 2 bulan yaitu pada November - Desember 2012

Populasi pada penelitian ini adalah penderita PGK . Populasi terjangkau adalah penderita PGK stadium 3,4, dan 5 di BLU.RSUP. Prof.dr R.D Kandou

Sampel pada penelitian ini adalah penderita PGK stadium 3,4,dan 5 yang memenuhi kriteria inklusi dan eksklusi di BLU.RSU. Prof.dr R.D Kandou

Kriteria Inklusi dalam penelitian ini adalah pasien PGK stadium 3,4,dan 5 dengan usia 30-50 tahun

Kriteria Eksklusi dalam penelitian ini adalah pasien PGK dengan TB Paru dan perdarahan ,yang tidak bersedia menjadi peserta penelitian ,Pasien PGK yang hamil,Pasien PGK yang sedang menjalani hemodialisis.

Variabel pada penelitian ini adalah $\mathrm{Hb}$, Saturasi transferin, dan Serum feritin.

Dalam melaksanakan penelitian ini, beberapa langkah yang perlu dilakukan adalah :

Subjek yang menjadi kelompok yang diteliti adalah penderita PGK stadium 3, 4, dan 5 di poliklinik Ginjal - Hipertensi bagian penyakit dalam BLU.RSU. Prof.dr R.D Kandou.

Pengumpulan data mengenai $\mathrm{Hb}$, Kreatinin, dan perhitungan LFG didapatkan melalui data hasil pemeriksaan pasien di poliklinik ginjal - hipertensi bagian ilmu penyakit dalam BLU.RSU. Prof.dr R.D Kandou periode November-Desember 2012. Pengumpulan data mengenai saturasi transferin dan serum feritin didapatkan melalui pemeriksaan laboratorium. Batasan operasional dalam penelitian ini antara lain:

1. Penyakit ginjal kronik adalah kerusakan ginjal lebih dari 3 bulan dengan atau tanpa penurunan LFG

2. Umur pasien adalah sesuai kartu identitas pasien

3. Jenis kelamin dinyatakan dalam laki-laki dan perempuan 
4. Derajat penyakit adalah tingkatan PGK stadium 3, 4 dan 5 ditentukan berdasarkan perhitungan LFG dengan formula dari Cockcroft-Gault

$$
\frac{(140-\text { Umur }) \times B B}{72 \times K P} \times 0,85 \text { (Pada wanita) }
$$

5. Anemia :Organisasi Kesehatan Dunia (WHO) mendefinisikan anemia sebagai konsentrasi $\mathrm{Hb}$ yang kurang dari $13 \mathrm{~g} / \mathrm{dL}$ pada pria, kurang dari $12 \mathrm{~g} / \mathrm{dL}$ pada wanita.

Instrumen yang digunakan untuk penelitian ini adalah : Alat tulis-menulis, Disposible 5cc, kapas alkohol, botol serum.

\section{HASIL PENELITIAN}

Berdasarkan hasil penelitian didapatkan umur rata-rata pasien adalh 43,36 tahun dengan umur paling muda yaitu 31 tahun dan paling tua 50 tahun.Nilai Hb rata-rata adalah 9,700 dengan nilai terendah 5,7 dan tertinggi 16,3.Nilai serum iron dengan rata-rata 43,32 dengan nilai terendah 12 dan tertinggi.TIBC memiliki nilai rata-rata 216,96 dengan nilai terendah 140 dan tertinggi.Saturasi transferin dengan nilai rata-rata 18,84, mempunyai nilai terendah 6 dan tertinggi 40. Serum feritin dengan nilai rata-rata 260,2764 dengan nilai terendah 11,99 dan tertinggi 1040,31.Karakteristik sampel penelitian dapat dilihat di tabel 1

Tabel 1. Karakteristik sampel peneliti

\begin{tabular}{|c|c|c|c|c|c|c|c|c|c|}
\hline & \multirow{2}{*}{$\begin{array}{c}\mathrm{N} \\
\text { Stati } \\
\text { stic }\end{array}$} & \multirow{2}{*}{ 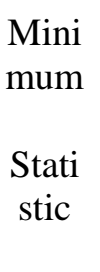 } & \multirow{2}{*}{$\begin{array}{l}\text { Maxi } \\
\text { mum } \\
\text { Stati } \\
\text { stic }\end{array}$} & \multirow{2}{*}{$\begin{array}{c}\text { Mea } \\
\mathrm{n} \\
\text { Stati } \\
\text { stic }\end{array}$} & \multirow{2}{*}{$\begin{array}{c}\text { Std. } \\
\text { Deviati } \\
\text { on } \\
\text { Statistic }\end{array}$} & \multicolumn{2}{|c|}{ Skewness } & \multicolumn{2}{|c|}{ Kurtosis } \\
\hline & & & & & & $\begin{array}{l}\text { Stati } \\
\text { stic }\end{array}$ & $\begin{array}{c}\text { Std. } \\
\text { Erro } \\
\mathrm{r}\end{array}$ & $\begin{array}{l}\text { Stati } \\
\text { stic }\end{array}$ & $\begin{array}{c}\text { Std. } \\
\text { Erro } \\
\mathrm{r}\end{array}$ \\
\hline Umur & 25 & 31 & 50 & $\begin{array}{c}43,3 \\
6\end{array}$ & 5,626 & $\begin{array}{c}- \\
, 773\end{array}$ & ,464 & $\begin{array}{c}- \\
, 163\end{array}$ & ,902 \\
\hline $\begin{array}{l}\text { Jenis } \\
\text { Kelamin }\end{array}$ & 25 & 1 & 2 & 1,40 &, 500 & ,435 & ,464 & $\begin{array}{c}- \\
1,97 \\
6\end{array}$ & ,902 \\
\hline $\mathrm{Hb}$ & 25 & $\begin{array}{c}11,0 \\
0\end{array}$ & $\begin{array}{c}163 \\
00\end{array}$ & $\begin{array}{l}88,6 \\
800\end{array}$ & $\begin{array}{c}36,9151 \\
3\end{array}$ & , 036 & ,464 & ,505 & ,902 \\
\hline $\begin{array}{l}\text { Serum } \\
\text { feritin }\end{array}$ & 25 & $\begin{array}{c}11,9 \\
9\end{array}$ & $\begin{array}{c}1040 \\
, 31\end{array}$ & $\begin{array}{l}260 \\
2764\end{array}$ & $\begin{array}{c}217,520 \\
28\end{array}$ & $\begin{array}{c}1,85 \\
1\end{array}$ & ,464 & $\begin{array}{c}6,10 \\
0\end{array}$ & ,902 \\
\hline SI & 25 & 12 & 95 & $\begin{array}{c}42,3 \\
2\end{array}$ & 17,712 & ,640 & ,464 & $\begin{array}{c}2,00 \\
2\end{array}$ & ,902 \\
\hline TIBC & 25 & 140 & 280 & $\begin{array}{c}216 \\
96\end{array}$ & 33,535 & - & ,464 & ,352 & ,902 \\
\hline $\begin{array}{l}\text { Saturasi } \\
\text { Transferin }\end{array}$ & 25 & 6 & 40 & $\begin{array}{c}18,8 \\
4\end{array}$ & 6,950 & ,778 & ,464 & $\begin{array}{c}2,38 \\
7\end{array}$ & ,902 \\
\hline
\end{tabular}

Hasil penelitian yang dilakukan di poliklinik Ginjal- Hipertensi BLU.RSUP. Prof. R. D. Kandou Manado periode November-Desember 2012 adalah didapatkan 25 pasien penyakit ginjal kronik yang memenuhi kriteria inklusi. Yang terdiri dari laki-laki 15 pasien $(60 \%)$ dan perempuan sebanyak 10 pasien $(40 \%)$. 


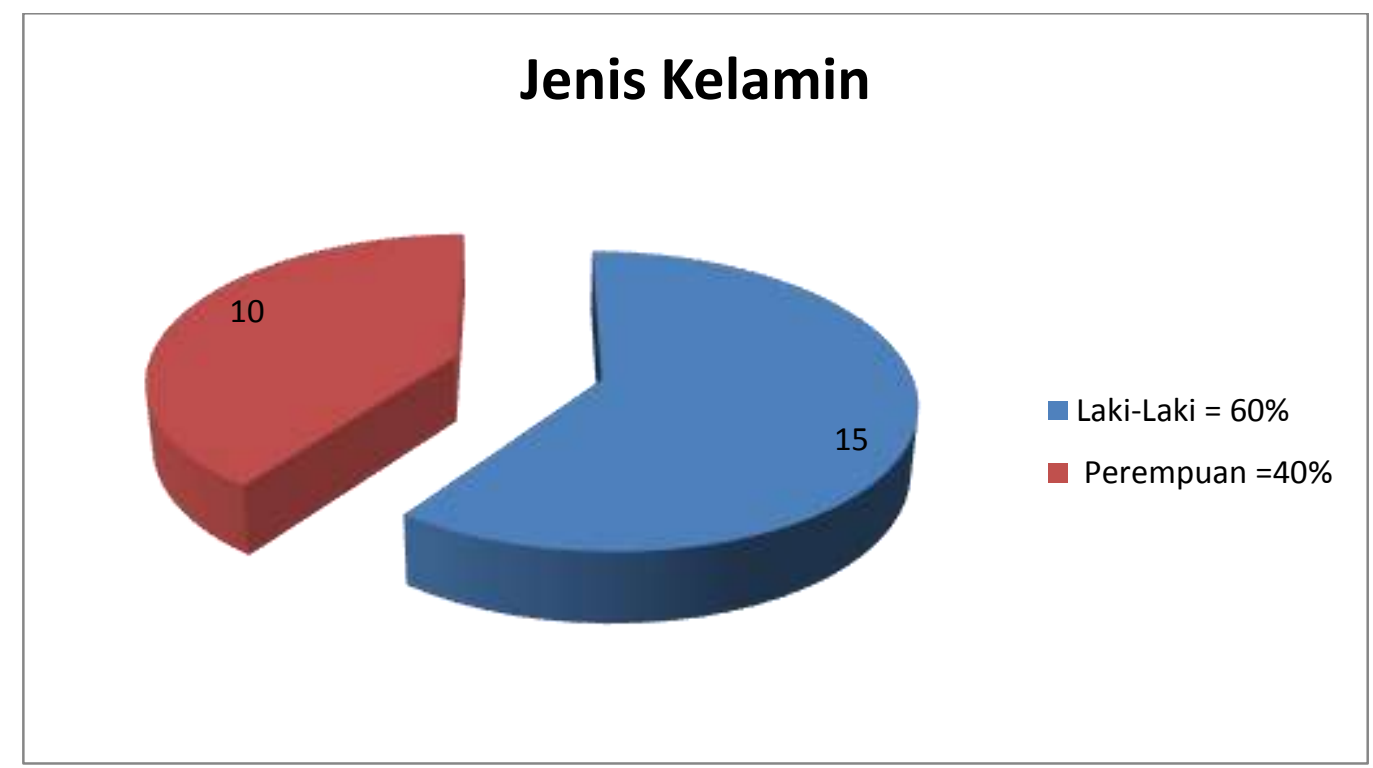

Gambar 1. Distribusi Pasien Penyakit Ginjal Kronik berdasarkan Jenis Kelamin

Dari 25 pasien yang diteliti, terdapat 5 orang (20\%) pasien stadium 3, 10 orang (40\%) pasien stadium 4 dan 10 orang (40\%) pasien stadium 5 (Gambar 3)

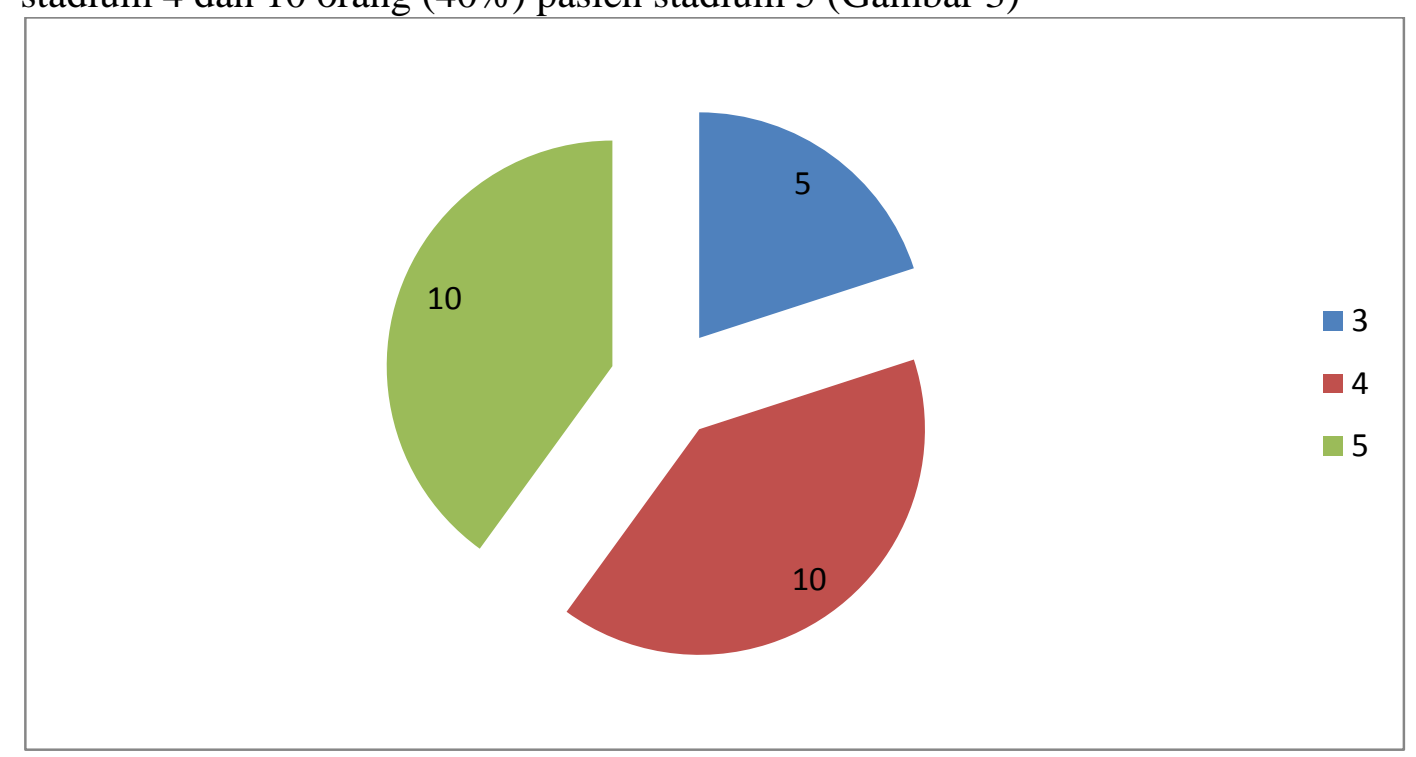

Gambar 3. Distribusi pasien berdasarkan stadium PGK

Berdasarkan derajat PGK distribusi umur pada tabel 2 dikelompokan berdasarkan 4 kategori umur. Kategori 30-35 tahun terdapat 1 orang stadium 4 dan 2 orang stadium 5. Kategori umur 36-40 tahun terdapat 2 orang stadium 3, dan 2 orang stadium 4. Pada kategori umur 41-45 terdapat 5 orang stadium 4, dan 3 orang stadium 5.Sedangkan pada kategori umur 46-50 tahun terdapat 3 orang pada stadium 3, 2 orang pada stadium 4 dan 5 orang pada stadium 5 . Total pasien 25 orang, seperti dapat dilihat di tabel 2 
Tabel 2. Distribusi umur berdasarkan derajat PGK

\begin{tabular}{lllll}
\hline Umur & PGK ST. 3 & PGK ST.4 & PGK ST.5 & Total \\
\hline $\mathbf{3 0 - 3 5}$ & $0(0 \%)$ & $1(4 \%)$ & $2(8 \%)$ & $3(12 \%)$ \\
& & & & $4(16 \%)$ \\
$\mathbf{3 6 - 4 0}$ & $2(8 \%)$ & $2(8 \%)$ & $0(0 \%)$ & $8(32 \%)$ \\
$\mathbf{4 1 - 4 5}$ & $0(0 \%)$ & $5(20 \%)$ & $3(12 \%)$ & $10(40 \%)$ \\
$\mathbf{4 6 - 5 0}$ & $3(12 \%)$ & $2(8 \%)$ & $5(20 \%)$ & $25(100 \%)$ \\
Total & $5(20 \%)$ & $10(40 \%)$ & $10(40 \%)$ & \\
\hline
\end{tabular}

Distribusi anemia berdasarkan derajat PGK, yaitu anemia defisiensi besi cukup terdapat 4 orang pada stadium 3, 6 orang pada stadium 4 dan 4 orang pada stadium 5. Anemia defisiensi besi fungsional terdapat 1 orang pada stadium 3, 4 orang pada masing-masing stadium 4 dan 5. Anemia defisiensi besi absolut terdapat 2 orang pada stadium 5, total keseluruhan pasien 25 orang, seperti yang dapat dilihat pada tabel 3

Tabel 3. Distribusi anemia berdasarkan derajat PGK

\begin{tabular}{lllll}
\hline Status Anemia & Stadium PGK & \multicolumn{2}{c}{ Total } \\
\hline & Stadium III & Stadium IV & Stadium V & \\
Anemia defisiensi besi cukup & 4 & 6 & 4 & 14 \\
Anemia defisiensi besi fungsional & 1 & 4 & 4 & 9 \\
Anemia defisiensi besi absolut & 0 & 0 & 2 & 2 \\
Total & 5 & 10 & 10 & 25
\end{tabular}

\section{PEMBAHASAN}

Pada penelitian yang bersifat observasional dengan rancangan potong silang ini untuk melihat gambaran anemia pada penderita PGK di poliklinik Ginjal-Hipertensi bagian/SMF Penyakit Dalam BLU.RSUP. Prof Dr. R.D.Kandou yang dilakukan selama bulan NovemberDesember 2012 mendapatkan hasil penelitian yaitu dari 120 pasien PGK rawat jalan didapatkan 25 pasien stadium 3, 4, dan 5 yang memenuhi kriteria inklusi.

Berdasarkan distribusi jenis kelamin didapatkan pasien terbanyak berjenis kelamin laki-laki yaitu $15(60 \%)$ pasien dan sisanya $10(40 \%)$ pasien perempuan. Sama halnya dengan penelitian yang dilakukan oleh Gilang Perkasa ${ }^{5}$ yang mendapatkan pasien PGK lebih banyak didapatkan pada pasien laki-laki. Pada data umur pasien, yang menunjukan angka PGK berdasarkan kelompok umur terbanyak menderita PGK adalah kelompok umur 46-50 dengan jumlah pasien 10 orang (40\%), sedangkan menurut Edgar $\mathrm{dkk}^{6}$ umur yang semakin tua akan mempengaruhi kejadian PGK, hail ini faktor LFG menurun dalam proses penuaan. Penurun LFG menyebabkan semakin sedikit neuron yang berfungsi, termasuk fungsi dalam produksi hormon eritropoietin yang berakibat pada terjadinya anemia, walaupun penyebab anemia pada PGK sendiri multifaktorial. ${ }^{7}$

Distribusi anemia berdasarkan derajat PGK yaitu anemia defisiensi besi cukup, anemia defisiensi fungsional, dan anemia defisiensi besi absolut. 
Pada penelitian ini pasien dengan status besi cukup sebanyak 4 orang stadium 3, 6 orang stadium 4 dan 4 orang stadium 5. Sedangkan anemia defisiensi besi sebanyak 1 orang stadium 3, 4 orang stadium 4 dan 6 orang stadium 5. Sedangkan pada penelitian yang dilakukan oleh Teddy $^{8}$ terdapat sebanyak $68 \%$ stadium 5 dan 32\% stadium 3-4 dari 25 pasien anemia defisiensi besi. Pada kedua hasil penelitian stadium terbanyak yang didapatkan adalah stadium 5.

Rata-rata serum feritin pada penelitian ini adalah 260,28 dengan nilai minimal 11,99 $\mathrm{ng} / \mathrm{dl}$ dan maksimal $1040,31 \mathrm{ng} / \mathrm{dl}$ sedangakan rata-rata saturasi transferin adalah 18,84 dengan nilai minimal $6 \%$ dan tertinggi $40 \%$ sedangkan pada penelitian yang dilakukan oleh Aber Baki dkk ${ }^{9}$ didapatkan rata-rata serum feritin adalah 92,1 dengan nilai minimal $12 \mathrm{ng} / \mathrm{dl}$ dan maksimal $214 \mathrm{ng} / \mathrm{dl}$ sedangkan saturasi transferin didapatkan rata-rata 22,96 dengan nilai minimal 7,4\% dan maksimal 48,4\%.

Serum feritin adalah fase akut reaktan dan ada perbedaan jenis kelamin (umumnya rendah pada wanita) membuat feritin sedikitbanyaknya kurang daripada test yang ideal untuk menentukan defisiensi besi. Saturasi transferin juga mempunyai beberapa fase akut reaktifitas, transferin mungkin meningkat pada keadaan peradangan atau infeksi, yangmana akan menurunkan saturasi transferin jika sirkulasi besi konstan. Transferin mungkin rendah karena penurunan sintesis transferin pada keadaan malnitrusi atau penyakit kronik, sehingga akan meningkatkan saturasi transferin jika sirkulasi besi konstan. ${ }^{10}$

Dikatakan defisiensi besi absolut jika kadar serum feritin $<100 \mathrm{ng} / \mathrm{ml}$ ditandai dengan tidak atau rendahnya besi, sedangkan defisiensi besi fungsional yaitu keadaan defisiensi besi relatif akibat cadangan besi pada sistem retikoendotelial terkunci dan tidak dilepas ke transferin sehingga saturasi transferin rendah walaupun kadar feritin normal atau tinggi . ${ }^{11}$

Hasil penelitian ini status anemia terbanyak berdasarkan derajat PGK adalah anemia defisiensi besi cukup yaitu 14 orang dengan nilai serum feritin $>100 \mathrm{ng} / \mathrm{ml}$ dan saturasi transferin $\geq 20 \%$, sedangkan anemia defisiensi besi fungsional sebanyak 9 orang dengan nilai serum feritin $>100 \mathrm{ng} / \mathrm{ml}$ dan saturasi transferin $<20 \%$ dan anemia defisiensi besi absolut sebanyak 2 orang dengan nilai serum feritin $<100 \mathrm{ng} / \mathrm{ml}$ dan saturasi transferin $<20 \%$. Sedangkan penelitian yang dilakukan oleh Aber Baki ${ }^{9}$ dkk dari 100 pasien pre-dialisis didapatkan 46 pasien non defisiensi besi sedangkan pasien dengan anemia defisiensi besi yaitu 56 pasien diantaranya 20 orang perempuan (37\%) dan 34 orang laki-laki (63\%).

Banyak pasien PGK dengan anemia mempunyai defisiensi besi tidak bisa memproduksi secara adekuat jumlah sel darah merah. Defisiensi besi dapat terjadi karena beberapa penyebab seperti kurangnya asupan makanan yang kaya akan besi, perdarahan, malabsorpsi, atau keganasan gastrointestinal. Feritin, yang merupakan protein yang banyak ditemukan pada makrofag dan hepatosit, merupakan cadangan besi dan juga penanda atas jumlah cadangan besi. Menggunakan cadangan besi membutuhkan transferin, yang merupakan transportasi pembawa protein,untuk membawa besi dari sistem retikuloendotelial dan usus ke sum-sum tulang. ${ }^{12}$

Hasil ini dapat dipengaruhi oleh beberapa hal seperti pemberian besi oral atau vitamin B12, Kelemahan penelitian ini adalah tidak dicatatnya terapi yang sedang dijalani pasien dan penyakit penyerta yang dapat mempengaruhi hasil pemeriksaan

\section{KESIMPULAN DAN SARAN}

Dari penelitian ini disimpulkan bahwa :

1. Gambaran anemia berdasarkan distribusi $\mathrm{Hb}$ didapatkan terendah 5,7 dan tertinggi 16,3 dengan rata-rata 8,868

2. Gambaran anemia defesiensi besi berdasarkan distribusi serum feritin didapatkan nilai terendah adalah 11,99 dan nilai tertinggi 1040,31 dengan rata-rata 260,2764 
3. Gambaran anemia defisiensi besi berdasarkan distribusi saturasi transferin niali terendah adalah 6 dan nilai tertinggi adalah 40 dengan rata-rata 18,84

SARAN

1. Pada pasien PGK perlu dilakukan evaluasi hematologi seperti $\mathrm{Hb}$, saturasi transferin dan serum feritin untuk mencegah anemia defesiensi besi yang dapat menimbulkan komplikasi

2. Perlu dilakukan edukasi yang baik pada pasien PGK tentang komplikasi anemia yang dapat menimbulkan komplikasi lain seperti kardiovaskular.

3. Pada penelitian ini tidak dicatat terapi yang sedang dijalani pasien sehingga tidak diketahui faktor-faktor yang menyebabkan status besi pasien, oleh karena itu untuk penelitian selanjutnya disarankan untuk mencatat terapi atau penatalaksanaan anemia yang sedang dijalani pasien.

\section{Ucapan terima kasih:}

Ditujukan kepada Prof.Dr.dr.Emma Sy.Moeis,SpPD-KGH selaku pembimbing I dan penguji I,Prof.dr.L.W.A.Rotty,SpPD-KHOM selaku pembimbing II dan penguji II , dan Prof.DR.dr.K.Pandelaki,SpPD-KEMD selaku penguji III yang telah memberi masukan dan saran dalam penulisan serta kepada semua pihak yang secara langsung maupun tidak langsung telah memberikan ide dan gagasan dalam penulisan ini.

\section{DAFTAR PUSTAKA}

1. Rasjidi Imam. Panduan Pelayanan Medik Model Inter disiplin Penatalaksanaan. Jakarta : EGC. 2008.Hal 38

2. Bliwise Donald, Kutner Nancy, Zhang Rebecca, Parker Kathy. Survival by Time of Day of Hemodialysis in an Elderly Cohort; 2001.

3. Arifin Miftahul, Yasmina Alfi, Anwar Zavita. Korelasi Antara Kadar Protein Urin dan Nilai Glomerular Filtration Rate Dalam Mengevaluasi Prognosis Gagal Ginjal Terminal Pada Pasien Hemodialisis Di Rumah Sakit Umum Daerah Ulin Banjarmasin Juli 2010.

4. Ayu Nyoman, Suega Ketut, Widiana Gede. Hubungan Antara Beberapa Parameter Anemia Dan Laju Filtrasi Glomerulus Pada Penyakit Ginjal Kronik Pradialisis;2010

5. Dokman Gilang. Profil Status Besi Pada Penderita Penyakit Ginjal Kronis Stadium 5 Yang Menjalani Hemodialisis Berkelanjutan di Instalasi Hemodialis RSUD Dr. Soetomo;2010

6. Lerma Edgar. Anemia of Chronic Disease and Renal Failure;2011.

7. Ayu Nyoman, Suega Ketut, Widiana Gede. Hubungan Antara Beberapa Parameter Anemia Dan Laju Filtrasi Glomerulus Pada Penyakit Ginjal Kronik Pradialisis; 2010

8. Teddy. 2011. Hubungan Hepcidin Dengan Feritin Serum Pasien Anemia Defisiensi Besi Pada Penyakit Ginjal Kronik. Tesis. Universitas Andalas. Hal 38-39

9. Baki Aber, Musa Nevine, Kamel Cherry. Iron Deficiency Among Anemic Pre-Dialysis Chronic Kidney Patients: Life Science Journal; 2012

10. Wish Jay. Assessing Iron Status; Beyond Serum Ferritin And Transferrin Saturation; 2006

11. Wiryani Cilik, Suwitra Ketut. Pengaruh Vitamin C Terhadap Kadar Serum Feritin Pada Pasien Gagal Ginjal Kronik Dengan Hemodialisis Reguler;2010

12. Taliercio Jonathan. Anemia and Chronic Kidney Disease ; What's Connection?; 2010. 